\title{
IDENTIFIKASI BORAKS DAN CEMARAN MIKROBIA PADA KARAK MENTAH DI SURAKARTA
}

\author{
Widya Anggraini Pamungkas, Nanik Suhartatik*, Akhmad Mustofa \\ Program Studi Teknologi Hasil Pertanian, Fakultas Teknologi dan Industri Pangan, \\ Universitas Slamet Riyadi \\ J1. Sumpah Pemuda No. 18, Joglo, Surakarta 57136 \\ *n_suhartatik@yahoo.com
}

\begin{abstract}
Abstrak
Karak adalah produk kering terbuat dari beras yang biasanya berbentuk lempengan tipis. Bahan baku karak berupa beras, garam, "bleng", dan bumbu lain. Bleng merupakan bahan yang mengandung boraks. Boraks melalui PerMenkes 722/MenKes/Per/IX/1988 dilarang digunakan sebagai bahan tambahan pangan karena berdampak negatif bagi kesehatan manusia seperti gangguan fungsi hati, kerusakan ginjal, mengganggu fungsi testis dan berdampak kematian. Penelitian ini bertujuan untuk menentukan tingkat cemaran boraks dan mikrobia pada karak nasi yang dijual di kota Surakarta. Kegiatan termasuk penelitian observasional dan menggunakan metode survei. Pengujian dilakukan di 5 kecamatan di Surakarta yakni Kecamatan Banjarsari, Pasar Kliwon, Jebres, Serengan, dan Kecamatan Laweyan dengan 2 pasar yang mewakili setiap kecamatan. Pengujian yang dilakukan meliputi uji kimia dan uji mikrobiologi. Uji kimia yang dilakukan berupa pengujian boraks dan kadar air. Hasil pengujian kimia menunjukkan 100\% sampel mengandung boraks dimana kandungan boraks berkisar antara 39,33-536 ppm dan 100\% sampel mentah mempunyai kadar air lebih dari SNI yaitu 20\%. Hasil mikrobiologi meliputi angka kapang, angka lempeng total, dan E.Coli banyak yang tidak sesuai dengan SNI 014307-1996. Hal ini menunjukan bahwa karak yang beredar di pasar tradisional di Kota Surakarta belum aman untuk dikonsumsi.
\end{abstract}

Kata Kunci : Karak, boraks, kapang, ALT, E. coli

Submit: 22 Februari 2021 * Revisi: 17 Maret 2021 * Accepted: 29 April 2021 * Publish: 10 Mei 2021 


\section{PENDAHULUAN}

Peningkatan kualitas sumber daya manusia agar menjadi sehat dan cerdas tidak luput dari kualitas bahan makanan yang dikonsumsi. Bahan makanan yang sehat wajib memenuhi kebutuhan gizi lengkap dan aman untuk dikonsumsi manusia. Dewasa ini pemerintah Indonesia mendorong pengem-bangan produk pangan lokal sebagai cara mewujudkan dan memperkuat kedaulatan pangan di daerah.

Penelitian Choirunissa, Karyantina \& Suhartatik (2018) tentang kandungan formalin pada ikan asin jambal roti di pasar tradisional di Surakarta melaporkan bahwa hasil kualitatif dari 24 sampel yang dilakukan pengujian, terdapat 21 sampel $(87,5 \%)$ yang teridentifikasi positif mengandung formalin. Boraks bisa telah diidentifikasi pada produk makanan seperti: roti bantal (Hardiana, Safrida, Adriani, Raihanaton, \& Maulida, 2020), bakso (Erniati, 2017), tahu (Nasution, Alfayed, Helvina, Siti, Ulfa, \& Mardhatila, A., 2018). Hal ini menunjukkan bahwa tingkat keamanan pangan yang beredar di masyarakat masih rendah.

Camilan lokal bertekstur kering yang sangat digemari oleh masyarakatt Indonesia, khususnya di Pulau Jawa, adalah kerupuk karak. Kerupuk karak adalah kerupuk yang diolah dengan menggunakan bahan dari beras atau nasi dengan penambahan bleng dan bumbu-bumbu secukupnya hingga menghasilkan gendar. Gendar dipotongpotong tipis menjadi bahan karak yang siap dijemur (Mustofa, Suhartatik, \& Sunarso, 2018). Dewasa ini pengawasan pemerintah terhadap pemasaran dan penggunaan bahan tambahan pangan kurang maksimal. Oleh sebab itu, tidak sedikit produsen makanan olahan, khususnya produsen yang bergerak pada lingkup skala industri rumah tangga menggunakan bahan tambahan pangan yang dilarang oleh Departemen Kesehatan Republik Indonesia.

Salah satu bahan tambahan pangan yang dilarang dan masih sering digunakan adalah boraks. Boraks juga terdapat di dalam bleng atau lebih dikenal dengan nama cetitet yang dipergunakan dalam pembuatan karak. Hal tersebut juga dibuktikan dengan larangan Departemen Kesehatan terhadap penggunaan bleng pada produk makanan karena mengandung boraks, yang dilarang dikonsumsi manusia (Yustina, Suhardjo, Jumadi \& Isharyani, 2009).

Boraks merupakan senyawa kimia yang berbentuk serbuk hablur kristal transparan atau granul putih tak berwarna dan tak berbau serta agak manis. Penambahan boraks pada proses pengolahan makanan bertujuan untuk meningkatkan kekenyalan, kerenyahan, serta memberikan efek rasa gurih dan kepadatan terutama pada jenis makanan ang mengandung pati (Wahed, Razzaq, Dharmapuri, \& Corrales, 2018). Meskipun tidak menunjukan efek negatif secara langsung ketika dikonsumsi, namun dampak negatif dari mengkonsumsi boraks bersifat akumulatif (tertimbun) sedikit demi sedikit dalam tubuh jika sering dikonsumsi akan terakumulasi pada jaringan tubuh di otak, hati, lemak, dan ginjal yang pada akhirnya memicu kanker dan dapat mengakibatkan kematian (Pane et al, 2012). Menurut anjuran Badan Pengawas Obat dan Makanan Republik Indonesia (BPOM RI) bahan tambahan yang dapat digunakan sebagai pengganti bleng padat dalam pengolahan kerupuk adalah STPP (Sodium Tripoly-phosphate). Hal tersebut tertuang dalam Peraturan Kepala Badan Pengawas Obat dan 
Makanan Republik Indonesia (PerKBPOM RI) No 16 tahun 2013 tentang Batas Maksimum Penggunaan Bahan Tambahan Pangan Garam Pengemulsi. Selain itu, faktor lain yang berpengaruh terhadap keamanan pangan yaitu : kadar air yang mempengaruhi masa simpan produk, dan juga faktor mikrobiologi seperti: Angka Lempeng Total, Angka Kapang dan juga E. coli. Penelitian ini bertujuan untuk mengidentifikasi penggunaan borak baik kualitatif maupun kuantitatif, kadar air karak dalam mentah, serta uji ALT, Angka Kapang dan juga Uji E. Coli.

\section{METODOLOGI PENELITIAN}

Pengambilan sampel dilakukan di 10 pasar tradisional dengan 2 pasar yang mewakili setiap kecamatan yang ada di Surakarta yaitu Pasar Legi dan Pasar Nusukan (Kecamatan Banjarsari), Pasar Gede dan Pasar Kliwon (Kecamatan Pasar Kliwon), Pasar Rejosari dan Pasar Mojosongo (Kecamatan Jebres), Pasar Harjodaksimo dan Pasar Gading (Kecamatan Serengan), serta Pasar Jongke dan Pasar Sidodadi (Kecamatan Laweyan).

Penentuan sampel karak yang diambil ditentukan menggunakan metode simple random sampling dengan rumus:

$$
(\mathrm{T}-1)(\mathrm{n}-1) \geq 15
$$

Keterangan:

$\mathrm{T}=$ Perlakuan (perbedaan lokasi pengambilan sampel)

$\mathrm{n}=$ Jumlah sampel yang diambil dari tiap lokasi

Sehingga diperoleh :

$$
\begin{aligned}
& (10-1)(\mathrm{n}-1) \geq 15 \\
& 9 \mathrm{n}-9 \geq 15 \\
& 9 \mathrm{n} \geq 24 \\
& \mathrm{n} \geq 2,67 \\
& \approx 3
\end{aligned}
$$

Jadi jumlah sampel berdasarkan rumus di atas adalah 3 sampel karak setiap satu pasar, maka total keseluruhan sampel adalah $3 \times 10=30$ sampel karak.

\section{Alat}

Alat yang digunakan dalam penelitian ini antara lain: timbangan, gelas ukur, oven, vortex, petridish, komporklistrik, tabung reaksi, erlenmeyer, beker glass, autoklaf, blender, inkubator, pinset, water bath, desikator, dan penjepit, spectrometer UV-Vis.

\section{Bahan}

Bahan yang digunakan dalam penelitian ini yaitu kerupuk karak mentah dan yang sudah digoreng sendiri, Plate Count Agar (Merck), Potato Dextrose Agar (PDA), NaCl (pa), dan Violet Red Bile Agar (Merck) dan bahan kimia untuk analisis.

\section{Parameter penelitian}

Parameter uji kimia yang dilakukan meliputi 2 faktor yaitu analisa kandungan boraks dan kadar air sampel secara mentah sedangkan untuk faktor mikrobiologi meliputi analisa ALT, analisa kapang, dan analisa E. coli. Analisa kandungan boraks secara kualitatif menggunakan metode Kertas Kunyit (Hartati, 2017) dan uji kandungan boraks secara kuantitatif dengan menggunakan Metode Spektofotometri (Fishman 1989) dengan modifikasi. Analisa kadar air menggunakan metode termogravimetri (AOAC, 1992), analisa ALT dilakukan dengan menggunakan Metode Tuang (Pour Plate) (Yunita, Hendrawan, \& Yulianingsih, 2015), uji angka kapang dengan menggunakan yang disampaikan oleh MA PPOM 90/MB/85 dan untuk analisa uji E. coli Metode Tuang (Pour 
Plate) (Haruni, Malaka, \& Ali, 2019). Data penelitian dianalisis beda nyata pada taraf signifikansi 5\% menggunakan SPSS for window. Jika ada beda nyata antar perlakuan, dilanjutkan dengan uji Duncan Multiple Range Test pada taraf signifikansi $5 \%$.

\section{HASIL DAN PEMBAHASAN}

\section{Uji Kualitatif Boraks}

Berdasarkan SNI 01-4307-1996 untuk produk kerupuk beras penggunaan boraks tidak diperbolehkan, akan tetapi penggunaan boraks masih ditemukan. Pengujian yang pertama dilakukan adalah uji kualitatif boraks terhadap karak dapat dilihat pada Tabel 1.

Tabel 1. Hasil Uji Kualitatif Boraks

\begin{tabular}{cccc}
\hline Pasar & $\begin{array}{c}\text { Kode } \\
\text { sampel }\end{array}$ & Perubahan warna & $\begin{array}{c}\text { Hasil } \\
\text { pengamatan }\end{array}$ \\
\hline Pasar Nusukan & NSK1 & Coklat & $(+)$ \\
(NSK) & NSK2 & Coklat Muda & $(+)$ \\
Pasar Legi & NSK3 & Coklat & $(+)$ \\
(LGI) & LGI1 & Coklat & $(+)$ \\
& LGI2 & Coklat & $(+)$ \\
Pasar Mojosongo & LGI3 & Coklat & $(+)$ \\
(MJG) & MJG1 & Coklat & $(+)$ \\
Pasar Rejosari & MJG3 & Coklat & $(+)$ \\
(RJS) & RJS1 & Coklat & $(+)$ \\
& RJS2 & Coklat Muda & $(+)$ \\
Pasar Gede & RJS3 & Coklat & $(+)$ \\
(GDE) & GDE1 & Coklat Muda & $(+)$ \\
GDE2 & Coklat Muda & $(+)$ \\
Pasar Ps. Kliwon & GDE3 & Coklat Muda & $(+)$ \\
KLW) & KLW2 & Coklat Muda & $(+)$ \\
Kasar Harjodaksimo & HJD1 & Coklat & $(+)$ \\
(HJD) & HJD2 & Coklat & $(+)$ \\
Pasar Gading & HJD3 & Coklat & $(+)$ \\
(GDG) & GDG1 & Coklat & $(+)$ \\
PDG2 & Coklat & $(+)$ \\
Pasar Jongke & GDG3 & Koklat & $(+)$ \\
(JGK) & JGK1 & Kuning & $(+)$ \\
Pasar Sidodadi & JGK2 & Kuning & $(-)$ \\
(SDA) & SDA1 & Kuning & $(-)$ \\
& SDA2 & Kuning & $(-)$ \\
& SDA3 & Coklat Muda & $(-)$ \\
& & Kuning & $(-)$ \\
& Coklat Muda & $(+)$ \\
& (+) & $(-)$ \\
\hline
\end{tabular}


Berdasarkan Tabel 1 dapat diketahui bahwa dari 30 sampel yang dilakukan pengujian, terdapat 24 sampel (80\%) yang teridentifikasi positif mengandung boraks. Hasil penelitian ini menunjukkan bahwa penggunaan boraks masih cukup tinggi di masyarakat. Hasil penelitian serupa yang menguji penggunaan boraks pada produk makanan yang ada di masyarakat juga menunjukkan kecenderungan yang tinggi juga seperti yang dilaporkan oleh Widelia, Farizal dan Narti (2018) yakni sebanyak 66,66\% dan Hartati (2017) yakni sebanyak $100 \%$. Hal tersebut tentu saja bertentangan dengan Peraturan Menteri Kesehatan No. 722/MenKes/ Per/IX/88, yang menjelaskan bahwa boraks merupakan bahan kimia yang dilarang penggunaannya untuk produk makanan.

\section{Uji Kuantitatif Boraks}

Keseluruhan sampel yang telah diuji secara kualitatif akan diuji lanjut secara kuantitatif. Hal ini dilakukan karena pada beberapa penelitian sebelumnya menunjukkan bahwa sampel dengan hasil uji kualitatif negatif akan tetapi setelah dilakukan uji kuantitatif menunjukkan bahwa sampel positif memiliki kandungan boraks. Hal serupa terjadi pula pada penelitian Hartati (2017), perbedaan limit deteksi uji kualitatif menggunakan kertas kunyit (turmerik) pada analisis boraks disebabkan karena perbedaan konsentrasi curcumin yang didapatkan pada saat ekstraksi kunyit (Suseno, 2019). Hasil uji kuantitatif boraks dapat dilihat pada Tabel 2.

Tabel 2. Hasil Uji Kuantitatif Boraks

\begin{tabular}{ccc}
\hline No & Pasar & Rata-rata $(\mathbf{p p m})$ \\
\hline 1 & Pasar Nusukan & $347,67^{\mathrm{ab}} \pm 136,5040$ \\
2 & Pasar Legi & $261,00^{\mathrm{ab}} \pm 281,0249$ \\
3 & Pasar Mojosongo & $354,33^{\mathrm{ab}} \pm 385,1082$ \\
4 & Pasar Rejosari & $402,67^{\mathrm{ab}} \pm 216,8141$ \\
5 & Pasar Gede & $227,67^{\mathrm{ab}} \pm 211,7979$ \\
6 & Pasar Kliwon & $536,00^{\mathrm{b}} \pm 47,6970$ \\
7 & Pasar Harjodaksimo & $167,67^{\mathrm{ab}} \pm 103,9631$ \\
8 & Pasar Gading & $246,00^{\mathrm{ab}} \pm 255,7831$ \\
9 & Pasar Jongke & $39,33^{\mathrm{a}} \pm 18,9297$ \\
10 & Pasar Sidodadi & $437,67^{\mathrm{b}} \pm 286,4583$ \\
\hline
\end{tabular}

Berdasarkan Tabel 2 menunjukkan bahwa dari keseluruhan pasar terindikasi positif mengandung boraks dengan konsentrasi terendah di Pasar Jongke yakni sebesar 39,33 ppm dan konsentrasi tertinggi di Pasar Kliwon yakni 536 ppm, dari ke sepuluh pasar rata-rata konsentrasi kandungan boraks yang terdapat pada karak yakni sebesar 302 ppm. Terkait hal itu banyak faktor penyebab boraks masih digunakan oleh produsen sebagai bahan tambahan 
pangan, seperti penjualan boraks yang dijual bebas sehingga sangat mudah didapatkan dan juga tingkat pengetahuan produsen mengenai boraks. Hal tersebut diperkuatkoleh penelitian Erniati (2017) yang menyatakan bahwa ada korelasi antara hasil uji laboratorium sampel bakso di SDN Lemahputro III Sidoarjo.

Pane, Nuraini dan Chayaya (2012) yang menyatakan bahwa makanan yang mengan-dung boraks dapat menyebabkan dampak negatif pada tubuh dimana pada dosis tertinggi yaitu $10-20 \mathrm{~g} / \mathrm{kg}$ berat badan orang dewasa dan $5 \mathrm{~g} / \mathrm{kg}$ berat badan anak-anak, sedangkan dosis terendah yaitu kurang dari 10-20 $\mathrm{g} / \mathrm{kg}$ berat badan orang dewasa dan kurang dari $5 \mathrm{~g} / \mathrm{kg}$ berat badan anak-anak, jika sering dikonsumsi akan terakumulasi pada jaringan tubuh di otak, hati, lemak dan ginjal yang pada akhirnya memicu kanker dan dapat mengakibatkan kematian.

\section{Uji Kadar Air}

Grafik uji kadar air karak mentah dan karak yang matang (sudah digoreng) pada penelitian ini dapat dilihat pada Tabel 3. Hasil uji kadar air tersebut menunjukkan bahwa pada sampel karak mentah, seluruh sampel yaitu sampel dari pasar A sampai dengan pasar J (100\%) melebihi ketentuan dari Standar Nasional Indonesia (SNI) dalam hal ini acuan yang digunakan adalah SNI Kerupuk Beras yaitu SNI 01-4307-1996 yang menetapkan bahwa kadar air kerupuk beras mentah yaitu maksimal $12 \%$. Tingginya kadar air kemungkinan disebabkan karena proses pengeringan yang masih kurang sempurna.

Dari data hasil uji beda nyata kadar air karak mentah menunjukkan sampel dari pasar $G$ berbeda nyata dengan sampel dari pasar $\mathbf{J}$ sedangkan sampel dari pasar A, pasar B, pasar C, pasar D, pasar $\mathrm{E}$, pasar $\mathrm{F}$, pasar $\mathrm{H}$ dan pasar I menunjukkan hasil yang tidak berbeda nyata.

Berdasarkan penelitian yang dilakukan, dari 30 sampel terdapat 6 sampel karak yang tidak memenuhi SNI (01-4307-1996) yakni Angka Lempeng Total (ALT) yang melebihi ambang batas maksimal sebesar 1 x $10^{6} \mathrm{CFU} / \mathrm{g}$ atau 1 juta koloni/g. Hasil penelitian menunjukkan bahwa sampel karak yang mempunyai nilai ALT tertinggi adalah dari sampel pasar $\mathrm{H}$ yakni sebesar 2,30 x $10^{6} \mathrm{CFU} / \mathrm{g}$. Hal ini dikarenakan sampel 040 terbukti tidak mengandung boraks yang bersifat mengawet-kan bahan pangan. Sampel karak yang mem-punyai ALT terendah adalah dari 017 yakni sebesar $1,00 \times 10^{5} \mathrm{CFU} / \mathrm{g}$. Sampel karak mentah ini positif mengandung boraks yang dapat menghambat pertumbuhan mikroba.

\section{Uji Kapang}

Kapang merupakan fungi yang secara visual terlihat seperti kapas atau benang yang terbentuk dari miselia dan spora kapang. Menurut Yulizar, Wientarsih dan Amin (2014), kapang biasanya tumbuh pada suhu kamar selama lebih dari 40 jam. Cara yang seringkali dipakai oleh produsen untuk menghindari pertumbuhan kapang adalah dengan menambahkan bahan pengawet agar produk bisa bertahan lebih lama (Prastika, 2020). Berdasarkan penelitian yang dilakukan, dari 30 sampel terdapat 12 sampel karak yang tidak memenuhi SNI (01-4307-1996) yakni kapang yang melebihi ambang batas maksimal sebesar $1 \times 10^{5} \mathrm{CFU} / \mathrm{g}$.

Kapang merupakan fungi yang memiliki filament (miselium) dan pertumbuhannya dipengaruhi oleh kadar air. Kapang biasanya tumbuh dengan kadar air kurang dari 14-15\%. Kapang dapat menghasilkan senyawa mikotoksin yang merupakan metabolit sekunder 
yang dihasilkan oleh kapang jenis tertentu selama proses pertumbuhan pada bahan pangan maupun pakan (Ismaiel \& Papenbrock, 2015).

Hasil penelitian menunjukkan bahwa sampel karak yang mempunyai nilai kapang tertinggi adalah dari sampel 043 yakni sebesar $4,85 \times 10^{5} \mathrm{CFU} / \mathrm{g}$. Sampel karak yang mempunyai kapang terendah adalah dari sampel 036 yakni sebesar $4,85 \times 10^{5} \mathrm{CFU} / g$. Sampel ini positif mengandung boraks yang dapat menghambat pertumbuhan mikroba. Tingkat cemaran mikrobia suatu bahan berhubungan dengan jumlah atau kadar air bahan pangan. Air dalam bahan pangan dapat digunakan untuk menunjang pertumbuhan mikrobia.

Tabel 4. Hasil Uji ALT, Angka Kapang dan E.coli

\begin{tabular}{|c|c|c|c|c|}
\hline Pasar & Kode sampel & $\begin{array}{c}\text { ALT } \\
\text { CFU/g }\end{array}$ & $\begin{array}{c}\text { Kapang } \\
\text { CFU/g }\end{array}$ & $\begin{array}{c}\text { E.Coli } \\
\text { APM/g }\end{array}$ \\
\hline \multirow{3}{*}{ Pasar A } & 011 & $1,40 \times 10^{5}$ & $7,15 \times 10^{4}$ & $1,90 \times 10^{2}$ \\
\hline & 012 & $3,55 \times 10^{5}$ & $2,97 \times 10^{5}$ & $1,00 \times 10^{1}$ \\
\hline & 013 & $3,25 \times 10^{5}$ & $2,28 \times 10^{6}$ & $8,50 \times 10^{1}$ \\
\hline \multirow[t]{3}{*}{ Pasar B } & 014 & $2,95 \times 10^{5}$ & $7,90 \times 10^{4}$ & $1,20 \times 10^{2}$ \\
\hline & 015 & $2,40 \times 10^{5}$ & $5,10 \times 10^{4}$ & $1,20 \times 10^{2}$ \\
\hline & 016 & $1,07 \times 10^{6}$ & $1,04 \times 10^{5}$ & $5,05 \times 10^{2}$ \\
\hline \multirow[t]{3}{*}{ Pasar C } & 017 & $3,45 \times 10^{5}$ & $7,20 \times 10^{4}$ & $1,55 \times 10^{2}$ \\
\hline & 018 & $1,38 \times 10^{6}$ & $9,00 \times 10^{4}$ & $5,50 \times 10^{1}$ \\
\hline & 029 & $1,60 \times 10^{5}$ & $5,95 \times 10^{4}$ & $1,50 \times 10^{1}$ \\
\hline \multirow[t]{3}{*}{ Pasar D } & 030 & $1,00 \times 10^{6}$ & $6,25 \times 10^{4}$ & $2,50 \times 10^{1}$ \\
\hline & 031 & $1,91 \times 10^{6}$ & $8,65 \times 10^{4}$ & $1,70 \times 10^{2}$ \\
\hline & 032 & $9,30 \times 10^{5}$ & $1,04 \times 10^{5}$ & $1,00 \times 10^{2}$ \\
\hline \multirow[t]{3}{*}{ Pasar E } & 033 & $5,50 \times 10^{5}$ & $7,80 \times 10^{4}$ & $1,55 \times 10^{2}$ \\
\hline & 034 & $3,25 \times 10^{5}$ & $7,70 \times 10^{4}$ & $1,60 \times 10^{2}$ \\
\hline & 035 & $4,15 \times 10^{5}$ & $1,29 \times 10^{5}$ & $1,55 \times 10^{2}$ \\
\hline \multirow[t]{3}{*}{ Pasar F } & 036 & $6,40 \times 10^{5}$ & $4,55 \times 10^{4}$ & $1,35 \times 10^{2}$ \\
\hline & 037 & $1,03 \times 10^{6}$ & $9,25 \times 10^{4}$ & $1,25 \times 10^{2}$ \\
\hline & 038 & $1,53 \times 10^{6}$ & $1,10 \times 10^{5}$ & $1,40 \times 10^{2}$ \\
\hline \multirow[t]{3}{*}{ Pasar G } & 039 & $4,60 \times 10^{5}$ & $9,60 \times 10^{4}$ & $7,50 \times 10^{1}$ \\
\hline & 040 & $5,15 \times 10^{5}$ & $4,85 \times 10^{5}$ & $2,25 \times 10^{2}$ \\
\hline & 041 & $6,35 \times 10^{5}$ & $6,60 \times 10^{4}$ & $5,45 \times 10^{2}$ \\
\hline \multirow[t]{3}{*}{ Pasar H } & 042 & $9,35 \times 10^{5}$ & $4,81 \times 10^{5}$ & $1,45 \times 10^{2}$ \\
\hline & 043 & $2,30 \times 10^{6}$ & $8,65 \times 10^{4}$ & $4,50 \times 10^{1}$ \\
\hline & 044 & $8,45 \times 10^{5}$ & $1,52 \times 10^{5}$ & $1,00 \times 10^{2}$ \\
\hline \multirow[t]{3}{*}{ Pasar I } & 045 & $6,35 \times 10^{5}$ & $8,35 \times 10^{4}$ & $2,50 \times 10^{1}$ \\
\hline & 046 & $7,60 \times 10^{5}$ & $1,23 \times 10^{5}$ & $9,50 \times 10^{1}$ \\
\hline & 047 & $9,60 \times 10^{5}$ & $6,75 \times 10^{4}$ & $1,65 \times 10^{2}$ \\
\hline \multirow[t]{3}{*}{ Pasar J } & 048 & $9,60 \times 10^{5}$ & $9,20 \times 10^{4}$ & $9,50 \times 10^{1}$ \\
\hline & 049 & $6,95 \times 10^{5}$ & $1,13 \times 10^{5}$ & $1,40 \times 10^{2}$ \\
\hline & 050 & $6,05 \times 10^{5}$ & $1,03 \times 10^{5}$ & $1,80 \times 10^{2}$ \\
\hline
\end{tabular}

Keterangan: data merupakan hasil rata-rata dari 2 kali ulangan (duplo) 


\section{Uji E.coli}

Escherichia coli merupakan bakteri patogen yang dalam jumlah besar dapat menyebabkan keracunan pangan. Escherichia coli adalah bakteri koliform yang dapat memfermentasi laktosa dan memproduksi asam gas pada suhu $37^{\circ} \mathrm{C}$. Escherichia coli sendiri merupakan bakteri gram negatif yang tidak membentuk spora (Ekawati, Siti \& Fakhmi, 2017). Berdasarkan penelitian yang dilakukan, dari 30 sampel tidak ada sampel karak yang memenuhi SNI (014307-1996) yakni ambang batas maksimal kurang dari 3 APM/g atau tiga APM/g.

Sampel yang mempunyai nilai $E$. coli tertinggi adalah dari sampel 044 yakni sebesar 5,45 x $10^{2}$ APM/g. Sampel karak yang mempunyai kapang terendah adalah sampel 012 yakni sebesar $1,00 \mathrm{x}$ $10^{1}$ APM/g. Sampel ini positif mengandung boraks yang dapat menghambat pertumbuhan mikroba.

Pada penelitian kali ini, diketahui bahwa kandungan boraks pada sampel tidak mempengaruhi keberadaan bakteri E.coli yang jumlahnya melebihi batas ambang Standar Nasional Indonesia (SNI) untuk produk kerupuk beras. Hal ini juga terjadi pada penelitian yang dilakukan oleh Windayani (2010) mengenai kandungan boraks dan cemaran mikrobia pada bakso daging sapi di Kabupaten Tangerang yang menunjukkan bahwa boraks tidak memiliki pengaruh yang nyata terhadap Total Plate Count (TPC), coliform, dan Staphylococcus aureus (P>005), hal tersebut terjadi karena kemungkinan jumlah boraks yang diberikan pada produk pangan terlalu sedikit untuk menekan laju pertumbuhan dan perkembangan mikroba.

\section{KESIMPULAN}

Semua karak yang dijual di kota Surakarta teridentifikasi mengandung boraks. Dengan kandungan terendah rata-rata per pasar yaitu 39,33 ppm dan kandungan tertinggi rata-rata per pasar yaitu $536 \mathrm{ppm}$. Sejumlah 12 dari 30 sampel mengandung kapang dengan jumlah yang berlebih. Karak termasuk dalam kategori bahan makanan yang tidak aman untuk dikonsumsi. Tindakan dari yang berwenang untuk menekan penggunaan boraks pada karak perlu segera dilakukan.

\section{DAFTAR PUSTAKA}

BPOM RI. (2013). Peraturan kepala Badan Pengawasan Obat dan Makanan RI No 16 tahun 2013 tentang batas maksimum penggunaan bahan tambahan pangan garam. Jakarta: Departemen Kesehatan Republik Indonesia

Ekawati, E.R., Siti, N.H.Y. dan Fakhmi, R.H.. (2017). Deteksi escherichia coli pathogen pada pangan menggunakan metode konvensional dan metode mutipex PCR. Jurnal Fakultas Ilmu Kesehatan Universitas Maarif Hasyim Latif Sidoarjo, 1(2).

Choirunisa, V. Karyantina, M., \& Suhartatik, N., 2018. Safety Assesment of Jambal Roti Salted Fish in Solo City. Proceeding of the $2^{\text {nd }}$ International Conference on Technology, Education, and Social Science. Solo, Indonesia.

Erniati.. (2017). Tingkat pendidikan, pengetahuan, sikap pedagang bakso dan penggunaan boraks pada bakso di SDN Lemahputro III 
Sidoarjo. Jurnal Kesehatan Lingkungan, 9(2), 209-216.

Hardiana, Safrida, Y. D., Adriani, A., Raihanaton, \& Maulida, S. (2020). Identifikasi kandungan boraks terhadap roti bantal komersil dan tradisional di Kecamatan Blang Pidie. Lantanida Journal, 8(1), 29-39.

Hartati, F.K.. (2017) . Analisis boraks secara cepat, mudah dan murah pada kerupuk. Jurnal Teknologi Proses dan Inovasi Industri, 2(1), 33-37.

Haruni, S., Malaka, R., \& Ali, H. M. (2019). Prevalence of microbial contamination and antibiotic residue in chicken meat, beef, and offal in South Sulawesi. Hasanudin Journal of Animal Science, 1(1), 1-11.

Ismaiel, A. A., \& Papenbrock, J. (2015). Mycotoxins: Producing Fungi and Mechanisms of Phytotoxicity. Agriculture, 5, 492-537.

Mustofa, A., Suhartatik, N., \& Sunarso. (2018). Pengembangan UKM Karak di Mojopuro, Wuryantoro, Wonogiri. In Prosiding Seminar Pengabdian kepada Masyarakat. (1): 59-64.

Nasution, H., Alfayed, M., Helvina, Siti F., Ulfa, R., dan Mardhatila, A.. (2018). Analisa kadar formalin dan boraks pada tahu dari produsen tahu di lima (5) kecamatan di kota Pekanbaru. Jurnal Photon, 8(2), 37-44.

Ratnaningsih, Rahardjo, B dan Suhargo.. (2007). Kajian penguapan dan penyerapan minyak pada penggoengan ubi jalar (Ipomoea batatas L.) dengan metode deepfat frying. Agritech, 27(1), 27-32.

Suseno, D.. (2019). Analisis kandungan boraks pada bakso menggunakan kertas tumerik, FT -IR spektometer dan spektrometer UV-
Vis. Indonesian Journal of Halal, 2(1): 1-9.

Wahed, P., Razzaq, A., Dharmapuri, S., \& Corrales, M. (2018). Determination of formaldehyde in food and feed by an in-house validated HPLC method Determination of formaldehyde in food and feed by an in-house validated HPLC method. Food Chemistry, 202(February 2016), 476-483. https://doi.org/10.1016/j.foodchem.201 6.01 .136

Widelia, P., Farizal, J. dan Narti, M.. (2018). Identifikaskkandungan boraks pada mie basah dikpasar tradisional Kota Bengkulu. Journal of Nursing and Public Health, 6(1), 58-62.

Windayani, K.. (2010). Kandungan boraks dan cemaran mikroba pada bakso daging sapi di Kabupaten Tangerang (Tesis, Sekolah Pascasarjana, Institut Pertanian Bogor, Bogor). Diakses dari https://repository.ipb.ac.id/jspui/bi tstream/123456789/58790/1/2010k wi.pdf

Yunita, M., Hendrawan, Y., \& Yulianingsih, R. (2015). Analisis Kuantitatif Mikrobiologi Pada Makanan Penerbangan (Aerofood ACS) Garuda Indonesia Berdasarkan TPC (Total Plate Count) Dengan Metode Pour Plate Quantitative Analysis of Food Microbiology In Flight ( Aerofood ACS ) Garuda Indonesia Based on the TPC. Jurnal Keteknikan Pertanian Tropis Dan Biosistem, 3(3), 237-248.

Yustina, I., Suhardjo., Jumadi dan H. D. Isharyanti.. (2009). Pengaruh bleng, air merang, dan STPP terhadap sifat organoleptik kerupuk puli rambak. Jawa Timur: Balai Pengkajian Teknologi Pertanian. 